\title{
The Importance of the Post-Mortem Examination and Its Place in Muslim Countries
}

\author{
M. G. Muazzam, M.B.B.S., F.R.C. Path. \\ Dhaka, Bangladesh
}

DOI: http://dx.doi.org/10.5915/20-4-13297

\begin{abstract}
The history of the post-mortem examination and its role in teaching anatomy, in medico-legal cases, and the clinical necropsy are discussed. Methods are suggested to improve the autopsy rates in Muslim countries.
\end{abstract}

Key words: Autopsy, post-mortem examination, necropsy.

Post-mortem examination also refers to 'necropsy' (nekros $=$ death, opsis $=$ view) or autopsy (autose self, opsy $=$ view). In the history of medical science we find that necropsy of the human body was not in practice till the 13 th century. Prior to that time knowledge of anatomy was obtained by the dissection of dead animals.

In medical science the autopsy or post-mortem examination is necessary for three purposes: (1) dissection of bodies by medical students to learn anatomy, (2) medico-legal autopsy to determine the actual cause of death in cases of sudden and unnatural deaths, and (3) autopsy to determine the cause of death when the attending physician is not sure about it.

DISSECTION Medical students give a great deal of time and energy during the first two years of their studies in dissecting bodies to learn anatomy. However, it is often difficult to obtain a sufficient number of bodies in Muslim countries. The early Egyptians probably gained some knowledge of human anatomy by their practice of trephining the skull and by the elaborate preparations of mummies. The Greeks obtained their knowledge of anatomy and physiology from dead animals, soldiers killed in the battle and executed criminals. During the period of the 8th -15 th centuries, Muslim medical scientists contributed enormously to all branches of medical science except anatomy. This was due to the lack of dissection of human bodies. These physicians tried to correct Greek errors of anatomy by dissecting chimpanzees and monkeys obtained from Africa.A dissec-

From the Ibn Sina Laboratories, Dhaka, Bangladesh

Reprint Requests: Dr. M. G. Muazzam, Ibn Sina Laboratories, Road 5A, House No 57, Dhanmond, R/A Dhaka,Bangladesh tion hall was established on the bank of the Tigris River by Khalifa Mutasim Billāh for this purpose.' 'Abdul Latif (1162-1231) and Ibn al-Nafis (1208-1288) were the principle contributors to anatomy and physiilogy. ${ }^{2}$

We must remember that it was never easy to obtain bodies for dissection even in Europe till the 19th century. In the early period of the European renaissance, scientists stole dead bodies from fresh graves to perform dissection in seclusion. Because of the scarcity of bodies, the first anatomy text, "Gray's Anatomy," was not published until $1858 .^{3}$ Dead bodies for dissection halls in Muslim countries are acquired somehow, though not in sufficient numbers. There is a general feeling, even among some modern educated persons, that dissection or post-mortem is against the teachings of Islam. This incorrect idea is based on misinterpretation of the following traditions (Ahādith) of Prophet Muhammad (PBUH): ${ }^{4}$

(i) According to Buraida ibn al-Hasib, the Prophet said, "... do not disfigure the dead bodies and do not kill the children."

(ii) "Imrān ibn Husain said, "whenever the Messenger of Allāh addressed us, he used to advise us to give charity, forbade us to disfigure dead bodies even if it was that of a non-believer. $\mathrm{He}$ forbade us to disfigure, to cut away the nose and ears and open up the abdomen even of a nonbeliever killed in the battle field." 4 These sayings of the Prophet were against the pagan custom of revenge as was done by Hind, the wife of 'Abu Sufyān (when they were non-believers) to the dead body of the general and companion of the Holy Prophet (PBUH), his uncle, Hamzah who was martyred in the battle of "'Uhud."

However, dissection of dead bodies to acquire knowledge does not come under the disfigurement forbidden by the Prophet (PBUH). It is unfortunate that the religious leaders of the past used such com- 
mendable sayings of our Prophet to prevent the scientific post-mortem examination. Islam is the greatest advocate of the study of science and the acquiring of knowledge. The misconception about autopsies by Muslim society put myself and my Muslim colleagues in serious difficulty in our student careers at Calcutta Medical College in 1946. Due to popular sentiment prevalent in the subcontinent of India during the Pakistan movement, Hindu Mahasabha leaders in Calcutta declared that the Muslim students must not be allowed to dissect Hindu dead bodies. Muslim dead bodies were not available for dissection and the college authorities stopped our dissection. Only recently has an Islamic scholar in an Islamic periodical of Bangladesh declared that the post-mortem examination for purely scientific purposes is legal. ${ }^{4}$

To allow Muslim students to gain a knowledge of anatomy, a sufficient number of dead bodies should be made available in all Muslim countries. In this regard the following steps should be taken:

(1) Medical scientists should hold a dialogue with the " 'Ulamâ"," (Muslim religious leaders) and convince them that dissection for gaining knowledge is not forbidden in Islam. (2) Before sending a dead body to the dissection hall, it must be ceremonially washed and shrouded according to Islamic tradition and the special prayer for the deceased (Janazah) should be offered. If the medical institutions take the responsibility to fulfill these religious obligations, there should be no social objection to using unclaimed dead bodies.

MEDICO-LEGAL AUTOPSY The main objective behind the post-mortem examiantion in the past was medico-legal. One of earliest such autopsies was performed on Pope Alexander V in 1410, due to the suspicious nature of his sudden and unexpected death. ${ }^{5}$ From history we come to know that when Julius Caesar (1000-44 B.C.) was murdered, his body was exposed in the Forum where the physician, Antistius, the first police surgeion in history, examined the corpse and found that one of the 23 wounds was fatal. Later, Emperor Justinian (483-565 A.D.) declared, "Physicians are not ordinary witnesses, but give judgement rather than testimony.” This was the first official acceptance of legal medicine. ${ }^{6}$ Pope Innocent III in 1209 provided for the appointment of doctors to the courts to determine the nature of fatal wounds.

Now medico-legal autopsy is obligatory in suspicious cases in all civilized countries, but the facilities available and the number of qualified forensic pathologists and technicians are not satisfactory in many Muslim states. Adequate laboratory facilities and cold rooms to keep dead bodies should be provided.

CLINICAL POST-MORTEN OR NECROPSY Post-mortem examination of some sort has probably been made since man first took a rational approach to disease. The earliest written record of a specific autopsy is that of one performed by William of Sachceto (Circa 1201-1280) on the nephew of the Marchese Pallavicini. ${ }^{5}$ Autopsy became increasingly common in the 16 th and 17 th centuries. Theophile Bonet (1620-1689) was the first to publish a systemtatized collection of autopsy findings in 1679, in his famous book, "Sepulchretum anatomicum sive anatomica practica." This was followed by another important book on autopsy, "De sedibus et causis morborum per anatomen indigatis," published by Giovanni Morgagni. In 1794, Mathew Baillie published an atlas and text book on morbid anatomy of the most important parts of the human body. This book, "The Morbid Anatomy," was the first modern text book of pathology. ${ }^{5}$ The development of the compound microscope in the 19th century and Virchow's (1821-1902) doctrine of cellular pathology added to the usefulness of the autopsy to medical science. The vast subject of pathology and morbid anatomy is based on autopsy findings and histopathology.

With the development of sophisticated diagnostic tools, clinicians are now in a better position to diagnose and assess the results of treatment. However, in spite of excellent clinical judgement and reliable diagnostic laboratory investigations, there are still many occasions when the diagnosis is not definite and patients die against all expected clinical prognosis. This is especially true when one deals with illnesses that have similar signs, symptoms or laboratory data. A clinical autopsy will not only detect our occasional failures but will also provide more confidence that our diagnosis and treatment were correct. Clinical autopsy my also reveal interesting and unusual findings that were not suspected clinically. An example of such a finding was the case of Hepatic Ascariasis, found on autopsy in a patient who died with the clinical diagnosis of amoebic liver abscess in the Dhaka Medical College.' A large number of adult ascaris lumbricoides were found in the billiary channels and abscess cavity, and one in the gall bladder.

Realising the importance of the clinical postmortem, it has become a regular feature in all large hospitals in the Western world since the mid 19th century. Willis $(1973)^{8}$ and Cameron $(1978)^{9}$ have emphasized the importance of the clinical autopsy in spite of sophisticated and advanced laboratory facilities available in recent years. Anderson (1979) ${ }^{10}$ states, "One of the best places to see pathology and to compare the clinical features of disease is the postmortem room."

Unfortunately, clinical autopsy is very rare in most developing countries and especially in the Eastern and Middle Eastern countries of Asia and northern Africa. This is true in spite of the fact that none of 
the major religions of the world, with the exception of Hinduism, places any absolute prohibition on autopsy.

Theophile Bonet in 1679 put into words the attitude of intelligent and progressive medical men towards autopsy when he said, "Let those who interdict the opening of bodies well understand their errors. When the cause of disease is obscure, in opposing the dissection of a corpse which must soon become the food of worms, they do not good to the inanimate mass, and they cause a grave damage to the rest of the mankind; for they prevent the physicians from acquiring a knowledge which may afford the means of great relief, eventually, to individuals attacked by a similar disease. No less blame is applicable to those delicate physicians, who from laziness or repungence, love better to remain in the darkness of ignorance than to scrutinize laboriously, the truth, not reflecting that by such conduct they render themselves culpable towards God, towards themselves and toward society at large."'s

In order to popularize clinical autopsy in Muslim countries:

(1) Medical scientists should hold dialogues with the religious leaders and social workers to convince them that clinical autopsy is needed for the development of medical science, to improve the knowledge of the physicians, and that it is neither un-Islamic, nor a disfigurement forbidden in the Hadith.

(2) In order to popularize the clinical autopsy, attending physicians should in all the cases where the diagnosis is equivocal, try to persuade the relatives of the deceased that a post-mortem examination is necessary to determine the actual cause of death. They must ensure that there will be no mutilation of the body and that it will be carefully sutured and cleaned so that there will be no difficulty in completing the subsequent religious rites. Though many may refuse, some will agree and thus, gradually the practice of clinical autopsy may be accepted.

(3) In those cases when medical certificate with cause of death is needed and the diagnosis is not definite, the clinician should refuse to sign the death certificate without an autopsy. In some cases even a partial autopsy may be enough to determine the cause of death.
(4) In news papers, periodicals, radio, television and public speeches the public should be educated about the importance of the clinical autopsy.

In this regard, Muslim physicians have a special responsibility to ensure that proper regard be afforded to dead bodies during the post-mortem, and to assure that no indecent public exposure of the body is allowed. Dissected parts not preserved for teaching should be properly disposed, preferably buried. If these rules are followed people will have no resentment against autopsy. If the doctors in the Muslim countries keep their patience and persist in educating the public about the importance of the autopsy, it will soon be a common practice in our hospitals and will contribute greatly in the development of medical science in our countries.

\section{References}

1. Ali M: Contribution of Muslims to Science (in Bengali); The Malik Library, Dhaka, Bangladesh $1981 ; 8: 39$.

2. Muazzam MG, Muazzam N: Contributions of early Muslim period to medical science: Basic sciences I, JIMA (In press)

3. Warwick R, Williams PL: Gray's Anatomy 35th ed. Longman 1973.

4. Rahim MA: Is Post-Mortem Legal? (in Bengali): Al-Ittehad, Ittehad al-Ummah, Bangladesh. 1987 (March) pp. 3-5.

5. Pearce JM: Autopsy, Collier's Encyclopedia, New York, P.F. Collier \& Son; 2: 568-569.

6. Cameron JM: Medical Science and Law, 1980; 20 (i): 3.

7. Muazzam MG, Khaleque KA and Ibrahim M: Hepatic ascariasis, J Trop Med Hyg 1960; 63:95.

8. Willis RA: The Spread of Tumours in the Human Body, 3rd edn. London: Butterworths Medical Publications, 1973; 400.

9. Cameron HW: The autopsy: its role in modern hospital practice, Investigative Cell Path 1978; $1: 297$.

10. Anderson JR: Muir's Textbook of Pathology, 11th ed. London: Edwards Arnolds, 1979: 2. 